\title{
The Relationship Between Human Capital and Financial Development: A Case Study of Turkey
}

\author{
Mehmet Nar ${ }^{1}$ \\ ${ }^{1}$ Department of Economics, Faculty of Economics and Administrative Sciences, Turkey \\ Correspondence: Mehmet Nar, Associate Professor, Department of Economics, Faculty of Economics and \\ Administrative Sciences, Artvin Coruh University, Turkey.
}

Received: August 28, 2019

Accepted: October 20, 2019

Online Published: October 27, 2019

doi:10.5430/ijfr.v11n1p157

URL: https://doi.org/10.5430/ijfr.v11n1p157

\begin{abstract}
The current growth literature has focused on the contribution of the human and financial variables to growth. This has led to an insufficient and low number of studies investigating the relationship between the financial and human variables. However, in order to establish effective public policies, the correlation between these two variables must be well known. In line with this necessity, this study aimed to contribute the relevant literature by investigating the relations of the two variables in the case of Turkey. To do so, firstly, the human and financial development index for Turkey was established. Subsequently, the financial development indicator was measured through the M2/GDP ratio, and the human capital indicator was measured through the education and health expenditures/GDP ratio. Through the econometric analysis carried out using the data from the period of 1998-2016, the existence of causality and the direction of this causality between the financial development and human capital accumulation in Turkey were investigated. As a result, it was observed that in Turkey, while financial development causes the accumulation of human capital, there is no significant causality directed from human capital to financial development.
\end{abstract}

Keywords: growth, human capital, financial development, education, health

\section{Introduction}

Every country in the world desires to develop enough to provide better welfare to their citizens. Yet, the development levels of countries vary greatly. There are numerous studies that have investigated the differences in the growth rates of countries. These studies have especially focused on the applications of developed and developing countries and the growth processes of Asian and European countries after World War II. Research shows that many factors such as foreign trade, public spending, tax burden, credit volume, banks, and privatization applications are associated with the concept of growth. The most recent studies in the literature regarding growth have focused on the contribution of financial intermediation and human capital accumulation which is the new version of the endogenous growth theory.

Development economics constantly refers to the necessity of financial development and human capital for economic growth. However, there are almost no studies investigating the existence of a causality relationship from human capital to financial development or from financial development to human capital. The small number of studies conducted in this context have revealed the existence of a causal relationship from financial capital to human capital in some countries and vice versa in others. The present study analyzed the direction of the causal relationship between human variables and finance with regard to Turkey. This study is of particular importance as it is one of the rare studies conducted in Turkey and in the literature in this field. In this study, firstly a literature review on the subject was conducted which was followed by an explanation of the materials and methods. Then, the findings of the econometric analysis were presented and finally the discussion of these findings was made in the conclusion section.

\section{Literature Review: Conceptual and Theoretical Framework}

Many studies regarding economic growth point to the importance of human capital. Human capital increases the efficiency in the economy and allows for the growth of physical capital at the same time (Agenor \& Montiel, 1996). The first discourse of the concept of human capital dates back to Adam Smith, a Scottish economist. The official use of the concept began in 1897 with Irving Fisher and through Mincer's work in 1958, Becker and Schultz's in the 
1960s, and Chiswick's in 1971, it was transformed into the popular concept that is widely used in the economy today (Goldin, 2014; Rutherford, 2002).

According to Adam Smith, the talent that is gained as a result of education is considered to be a part of social fortune, i.e., national income, excluding personal wealth. In his work, Irving Fisher used the term "living capital" instead of human capital. Jacob Mincer discussed the concept of human capital in his article on "income differences in American societies" that he wrote 60 years ago. This article draws attention to the impact of education on income distribution. According to Mincer, one of the causes of income inequality is the differences in human capital. He emphasized the importance of post-school job training and vocational education in addition to formal education in the elimination of inequality. Mincer, who touched upon the indisputable role of vocational education in the elimination of income inequality and preventing poverty, believed that individuals needed to become more productive in order to achieve economic growth. If a rational distribution of resources is desired in the economy, it is necessary to increase human capital accumulation (Goldin, 2014; Tiexeria, 2007).

Schultz (1961) focused on the impact of human capital on economic growth and underlined that the differences between incomes is a reflection of the differences in education and health. In addition, he argued that providing individuals with the opportunity to migrate within the country allows individuals to develop their abilities and to get more shares from the income. In their study, Becker and Schultz (1964) attributed the concept of human capital to the factor of education as they believed that knowledge, skills, and value-added gained through education increase investments in the long-term, strengthens the economy and raises the individual's quality of life. They concluded that, although human capital investments are considered as a cost in the short term, the return on investment exceeds the costs in the long term. Therefore it is important to allow individuals to use long-term public and private sector credits for this purpose. Chiswick (1971) stated that injustice in income distribution can be partially recovered by human capital investments. He drew attention to the importance of formal education and post-school education and stated that the inadequacy in human capital investments causes individual and regional income differences (Tiexeria, 2007).

Since the 1980s, humanity has experienced a development in the information society. The concept of human capital has become even more important and the focus of growth literature. Physical capital is prominent in the neoclassical growth model developed by Solow and Swan (1956). Nonetheless, internal growth models regarding (i) physical capital, (ii) human capital (Lucas, 1988), and (iii) information status (Romer, 1986) together have become one of the most popular growth theories that prioritize investment in human beings. On the other hand, physical capital in the neoclassical growth model has shown a decreasing marginal revenue in the production process. However, internal growth models that highlight human capital also focus on the increased return of capital as the information provided through education supplies the necessary technological knowledge to develop new production methods. In other words, technological development raises human capital stock. Thus, the productivity factors of the production process are affected positively, which also allows for the differences between countries in terms of per capita income and growth rates to be explained. As a result, while the neoclassical growth model refers to the decreasing marginal revenue concept for capital, internal growth models emphasize the marginal return of capital and the increasing growth in economies (Agenor \& Montiel, 1996).

Referring to the importance of human capital, Lucas (1988) stated that the production of goods and services depends not only on the specific information stock but also on the total information stock. For this reason, public education is necessary in addition to special education as it creates a social utility with the spillover effect. The provision of state-owned education and health services is even more important, especially as it allows individuals with low income to access these services. The increase in the number of qualified individuals in society also increases the stock of human capital. Consequently, societies composed of more healthy and educated individuals are considered fairer in terms of income distribution, more democratic in terms of management mentality and more stable in terms of growth rates (Agenor \& Montiel, 1996).

Barro (1990) discussed the positive contribution of public investments in education and health to public growth and emphasizes the importance of transferring public investments to such efficient areas (Barro,1990). Rebelo stated that human capital is as important on growth as physical capital. Just like Lucas, he acknowledged that individuals with more human capital are more productive regardless of their ability levels (Rebelo, 1991). In this sense, the contribution of human capital to growth in developing countries may be higher than that of physical capital. Studies have shown that many countries have achieved high rates of growth with labor input. Especially, the contribution of human capital to growth in Asia is one of the important examples to be underlined (Agenor \& Montiel, 1996; Agenor $\&$ Montiel, 2015). 
Another important point in terms of economic development or growth is the issue of how capital is monetized or measured. It is understood that in the calculation of the human capital criteria, such as education rates, schooling rates, school enrollment rates, survival rates (Ferreira \& Hamilton, 2010), health-related expenditures, individuals' ability to generate income, employment rates, wage differentials, and migration opportunities (Bartolo, 1999; Rutherford, 2002) are taken into account. Considering the various characteristics of individuals, such as age and gender, the monetary value of human capital has been tried to be estimated for each country (Hamilton \& Liu, 2013). However, discussions on how human capital can be measured are still continuing. For example, educational expenditure levels may not show how good human capital is in different countries. According to some economists, all fields of higher education do not contribute to human capital at the same level. For instance, it is said that human capital investments in the field of medicine will relatively make more contribution to the capital stock of a country (Rutherford, 2002).

The role of human capital in economic development is very clear. One of the main reasons why countries with rich resources live in hunger is that they do not have an educated and qualified workforce. For example, the fact that Nigeria, which has the world's largest oil and diamond deposits, is one of the 10 poorest countries of the African continent is a clear indication of this situation. Moreover, the policies of developed countries towards attracting qualified human capital from underdeveloped and developing countries lead to more poverty in these countries. The visa designed by the US for highly talented people is also an example of this. In addition, as a similar example, Britain gives residence permits to people coming from countries such as Bulgaria and Romania, provided they are qualified.

Economists, on the other hand, refer to the positive contribution of financial development to economic growth. According to these economists, the evolutionary development of financial transactions actually summarizes the process of human development. In the historical process, societies that first turned to the clearing system for their trade-offs and in order to produce goods and services, have now turned to more sophisticated tools such as metal money, paper money, and plastic money (credit card). In the 20th century, paper money has gradually been replaced by electronic money in parallel with the development of information technologies. This has increased the speed, quality, and complexity of financial transactions (Lorimer, 2012; Wikipedia, 2017).

In particular, the concept of information society, which was first introduced in the 1970s, has come to describe the social structure based on computer and communication technologies. While the progress made in information technologies transforms the function of communication, information, and mass media, this, in turn, enables the formation of global markets. It is observed that trade is growing exponentially, new derivative markets enter the agenda intensively, and complex financial instruments are emerging. In particular, the concept of securitization parallel to rapid globalization takes its place among the adopted views of the modern capitalist era. The fact that transactions in financial markets occur with the help of just a computer key reduces transaction costs. This allows financial intermediation activities to expand as much as possible (Kyrtsis, 2010; Mattelart, 1996; Mosco, 2009).

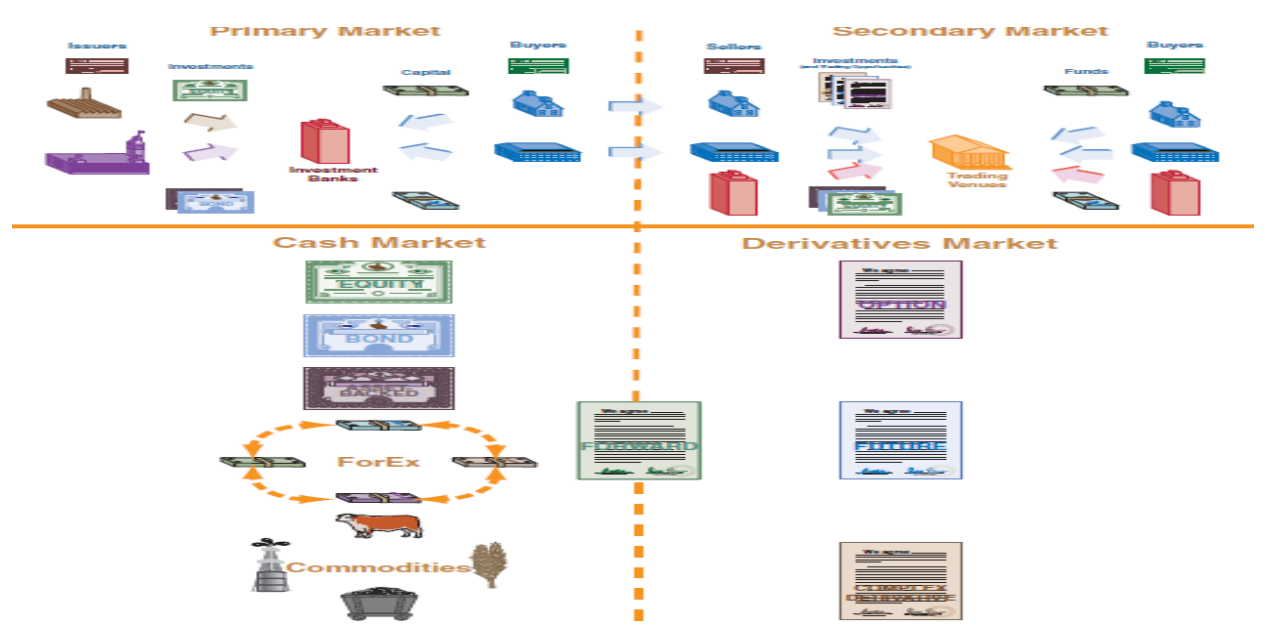

Figure 1. Taxonomy of markets

Source: (Williams, 2011) 
The market is the place where buying and selling transactions are carried out for the mutual shopping activities of goods and services. The secondary market is situated against the primary market, while the derivatives market is situated against the cash market. The financial market is the mechanism that provides capital and credit exchange in the economy and is divided into two as money market and capital market. While the money market consists of short-term debt instruments, the capital market consists of long-term debt instruments. The stock market, bond, commodity market, and foreign exchange market are the most common examples of the financial markets (Nar, 2014a; Williams, 2011). The main aim of these markets is to provide resource flow to sectors with the deficit from sectors with the surplus. Hence, financial markets perform three main tasks: (i) reduce information processing costs, (ii) diversify trade, and (iii) accelerate financial development by realizing risk management (Haan et al, 2009).

In an economy, financial development firstly raises saving rates. It allows the borrowing options in the economy to increase and the productivity of capital to also increase. Then, interest rates fall and the distance between the borrower and the lender decreases. This is one of the main indicators of financial development in a country. Finally, the share of savings allocated to investments increases. Thus, the conduit effect is formed and growth increases as the investments increase. The development of financial markets allows resources to be directed to high yield projects. Financial intermediaries provide better protection for the economy with diagnosing shocks. Entrepreneurs can access more robust data on investment projects as well as evaluate and process this information. Financial intermediation provides entrepreneurs with access to efficient technology and increases firms' profitability rates. Another function of financial intermediation is to reduce risks and act as insurance. It encourages entrepreneurs to invest in riskier but more productive technologies and distributes the existing risks. It also contributes to the stability in the economy by identifying liquidity shocks (Agenor \& Montiel, 1996; Loayza \& Ranciere 2005).

A study conducted by Greenwood \& Jovanovich (1990) drew attention to capital productivity with regards to the concept of financial intermediation. According to their model, financial intermediaries allow capital to be transferred to areas that are more efficient. This contributes to the prevention and reduction of economic shocks resulting in higher growth. Meanwhile, Bencivenga \& Smith (1991) stated that banks, one of the financial intermediary institutions, reduce the investment waste by moving the "liquidity" to areas that are more effective from low value-added areas and pointed out that banks are institutions with special importance in this regard.

The first literature study to determine the direct relationship between financial development and growth was conducted by McKinnon (1973) and Shaw (1973). Similar to McKinnon and Shaw, Pagano (1993) stated that financial intermediation can increase savings rates in the economy. Increased investments due to increased savings also accelerate growth. The data of this study showed that the countries with higher growth rates are the countries with higher savings, investment and export rates compared to medium and slow growing economies. According to Pagano, inadequate financial intermediation activities in an economy not only lead to negativity regarding savings and investment rates but also decrease capital efficiency. Levine and Renelt (1992) reported that investment rates had a positive and significant relationship with human capital as well as growth rates (Agenor \& Montiel, 1996; Agenor \& Montiel, 2015).

Roubini \& Salai-Martin (1995) discussed the negative effects of the financial pressure from governments on the financial markets. According to their study, in particular, an increase in tax rates or in the required reserve ratio imposed a limitation on the portfolio investments of financial intermediaries. In turn this leads to the loss of savings directed to financial intermediaries (i.e., banks, insurance companies, and pension funds) that accept deposits. While some of the financial funds are shifted to less efficient areas, the amount of investment decreases and growth slows down.

On the other hand, the role and importance of financial capital on growth will likely continue with increasing like human capital. Considering that both the impact of human capital on growth and the contribution of financial intermediation activities to economic growth are highly evident, the reason that they are the focus point of many studies is an indication of their importance. However, there are very few studies projecting the direct relationship between these two variables, which are extremely important in terms of growth. In fact, besides the contribution of the human factor in financial development, the effect of financial development on human factor should be analyzed thoroughly. Such analysis will;

(i) allow us to reach more realistic results in explaining the difference in the growth experiences between countries,

(ii) allows the creation of alternative models,

(iii) guide the bureaucracy on how to program the existing policies, 
(iv) increase the success of public policy (Agenor \& Montiel, 2015).

In order to create effective public policies, it is necessary for governments to design their policies to provide both "human" and "financial" accumulation. This requires a good knowledge and understanding of the relationship between the two (Hatemi \& Shamsuddin, 2016).

In the theoretical literature, studies on the role of human capital in financial activities indicate that the expertise and experience gained through scientific education increases the quality and quantity of financial intermediation (Bottazzi et al, 2004). Research shows that the increase or deepening in human capital facilitates access to financial markets and minimizes the constraints in these markets. Furthermore, an increase in literacy rates can minimize the growth losses caused by limited financial intermediation activities. On the other hand, in regions with low literacy rates, growth losses reach significant rates (Kendall, 2012). In addition, countries with a high human capital quality can benefit more from financial development as countries with competent scientists also have the necessary technology for financial markets, hence, they have important advantages for financial development and growth (Sharma, 2016).

Developing financial intermediation activities are shifting investments to areas with high growth potential which enables the development of corporate policies and the enhancement of their functioning (Bottazzi et al, 2004). In addition, savings are activated effectively, risks can be managed, and the economy is invested in sectors that are more productive. The limited level of innovation in financial markets constitutes a restrictive effect on the investment level. While developmental differences among countries exist, low financial intermediation activities lead to lower human capital and employment levels (Evans et al, 2002; Kendall, 2009; Sharma, 2016). The development of the financial system directly contributes to the development of human capital and increase in welfare (Outreville, 1999). This also helps in the understanding of the "linear" relationship between financial development and human capital (Parente \& Prescott, 1994).

Empirical literature ignores the relationship between finance and human capital to a great extent. As the researches focus on the effect of these two variables on growth, the studies about their interaction remain extremely inadequate and limited. The study conducted by Outreville (1999) evaluated the relationship between human capital and financial development, using data from 57 countries with different economic levels. In his study, where human capital accumulation was measured with the "university graduate labor force ratio" and financial development with the "money supply (M2) as \% of gross domestic product (GDP)" ratio, a positive relationship was achieved between these two variables. Accordingly, it can be concluded that human capital accumulation is one of the main determinants of financial development. It can be seen that human capital accumulation in these countries results in financial development (Demirci \& Ozyakışır, 2017; Hatemi \& Shamsuddin, 2016; Outreville, 1999). Furthermore, Evans, Green, and Murinde (2002) carried out a study with data from 82 countries dating between 1972 and 1992. They analyzed financial development through the ratio of M2/GDP and domestic credit to GDP ratio, and human capital accumulation through "primary and secondary enrolment ratio/schooling rate". According to their results, besides the linear relationship between human capital accumulation and financial development, a heavy effect of these two variables on growth was also determined (Evans et al, 2002). In a study conducted in 2011 on the national data of India from 1975-2007, the financial index was formed as "M3/GDP", and human index as "share of education expenditures in total public expenditure". In addition to a positive correlation which was found in the comparison, a causal relationship from human capital to financial development was found between the human capital index and financial development (Demirci \& Ozyakışır, 2017).

In a study conducted in 2014 in Pakistan by the South Asian Association Regional Cooperation Organization (SAARC) with regards to the "M2/GDP" ratio and "gross enrollment ratio", a positive relationship was found between the two and showed the existence of a causal relationship from financial capital to human capital. According to this study, financial development increases production capacity in the economy and contributes significantly to service power, i.e. employment. In addition, in a study by Hatemi and Shamsuddin in Bangladesh, the conclusion was made that, between the human capital indicator calculated with the Barro-Lee index and the financial development measured over the domestic credit ratio given to the private sector ( $\%$ of GDP), the existence of a substantial causal relationship from financial developments to human capital was present. According to their study, financial development in Bangladesh increases the human capital accumulation or the investment in human. However, in contrast to expectations, there is no significant causality from human capital to financial development (Hatemi \& Shamsuddin, 2016). 


\section{Econometric Analysis}

\subsection{Materials and Methods}

The present study addressed the relationship between human capital and financial development in Turkey. The study examined data from the period of 1998-2016 and for the financial development indicator (FINANCE), the ratio of M2 to GDP was used.

In general, the ratio of monetary indicators and credit sizes to GDP are used to measure financial development. However, M1-money supply is not used very often as it does not have a strong relationship with the economic development level. On the other hand, since the ratio of M2 and M3-money supply to GDP has a strong effect on measuring the size of financial intermediation, it has been the focus of numerous studies (Feldman \& Gang, 1990; King \& Levine, 1993). In addition, the education/health index was formed for the human capital indicator (HUMAN).

Education is the most important factor in measuring human capital. The education factor broadly covers on-the-job training/job shadowing and apprenticeship education as well as formal/organized education and non-formal education. Then, the capital accumulation gained through health services is the next important factor (Dwivedi, 2010). This is because human capital accumulation is a result of investments in healthcare as well as in education. Healthcare investments gain value depending on the increased life expectancy of the population of a country and decreasing morbidity rates. With such investments, the productivity of people can be increased as healthy and educated individuals are considered more productive (Wal, 1999).

To establish the education and health indicators, the ratio of education expenditures to GDP and the ratio of health expenditures to GDP were used, respectively.

Education/health indexes that are aimed at measuring human capital are generally calculated via the rate of healthy living and schooling. Therefore, these determinants were predominantly used in this study. Education and health expenses, however, are calculated in proportion to GNP. The main reason for this is that indexes such as the World Bank Human Capital Index, OECD Better Life Index and Barro-Lee Index can give real results of the human capital of a country. However, the scores given to the criteria (education, health, income, property) can be affected by subjective factors such as the researcher's standard of judgement, ideological and religious views, gender and ethnic origin. This makes it difficult to evaluate the "thing" that is being measured and can lead to questionable results. For this reason, an objective evaluation was carried out by measuring the education and health expenses in proportion to GNP. Likewise, economists and social scientists have long been using the GNP (Gross National Product) method, which is one of the traditional approaches in measuring the prosperity level. Because measuring the changes in wealth and well-being using GNP data is reliable and simple. The fact that GNP measuring techniques are similar in all countries ensures this reliability and simplicity (Nar \& Nar, 2019).

The following formula was utilized for the education/health index.

$$
\text { Index }=\frac{\text { Value of the relevant year }- \text { the smallest value }}{\text { the largest value }- \text { the smallest value }}
$$

The maximum theoretical value for both the education and health indexes was 100 while the minimum theoretical value for both indexes was 0 .

The data used in this study was obtained from the databases of the Turkish Statistical Institute (TurkStat), Central Bank of the Republic of Turkey (CBRT), and the World Bank (WB). Furthermore, missing data in the education and health expenditures were estimated with interpolation and extrapolation methods.

\section{Findings}

The summary statistics for the FINANCE and HUMAN variables used in the study are given in Table 1.

Table 1. Summary statistics

\begin{tabular}{lll}
\hline & FINANCE & HUMAN \\
\hline Average & 0.04 & 0.05 \\
\hline Median & 0.04 & 0.05 \\
\hline Standard deviation & 0.01 & 0.01 \\
\hline
\end{tabular}




\begin{tabular}{lll}
\hline Kurtosis & -1.80 & -1.90 \\
\hline Skewness & -0.32 & 0.03 \\
\hline Interval & 0.04 & 0.02 \\
\hline Smallest & 0.02 & 0.04 \\
\hline Largest & 0.05 & 0.06 \\
\hline
\end{tabular}

According to these statistics, the financial development indicator varies between the interval of 0.02 and 0.05 . The FINANCE variable, which has an average value of 0.04 for the period considered for this study, has a left-skewed structure with a negative skewness coefficient. In addition, the kurtosis coefficient of this variable has a negative value which shows that the FINANCE variable has more kurtosis than the normal distribution.

The human capital indicator varies between the interval of 0.04 and 0.06 . The HUMAN variable, which has a mean value of 0.05 for the period considered for this study, has a right-skewed structure with a positive skewness coefficient. In addition, the kurtosis coefficient of this variable is negative which shows that the HUMAN variable has more kurtosis than the normal distribution.

In the statistical studies, in order to apply many analyzes, the distribution of data must be normal or close to normal (Kalayc1, 2006). Therefore, the fact that the skewness and kurtosis coefficients are close to 0 within the \pm 1 limits or the skewness and kurtosis indices close to 0 within the limits of \pm 2 is shown as evidence for the normal distribution of the data (Demir et al, 2016). These results confirm that the given data are available for analyses.

In this study, the relationship between financial development and human capital was discussed in the context of causality. Therefore, the Granger causality test was used to determine the existence and direction of a time-dependent lag relationship between the two variables, i.e., the causality.

The first step of the Granger causality test with two variables, such as and, requires the estimation of the following VAR model:

$$
\begin{gathered}
y_{t}=\alpha_{1}+\sum_{i=1}^{n} \beta_{i} x_{t-i}+\sum_{j=1}^{m} \gamma_{j} y_{t-j}+e_{1 t} \\
x_{t}=\alpha_{2}+\sum_{i=1}^{n} \theta_{i} x_{t-i}+\sum_{j=1}^{m} \delta_{j} y_{t-j}+e_{2 t}
\end{gathered}
$$

The $e_{y t}$ and $e_{x t}$ error terms are the process of white noise where there is no relation between them. The white noise process is a special and important type of stable process in econometrics. It defines the probabilistic process that expresses a pure random situation (Yalta, 2011). There are four possible situations in the model: (i) $x_{t}$ causes $y_{t}$, (ii) $y_{t}$ causes $x_{t}$, (iii) there are two-way causality between $x_{t}$ and $y_{t}$, or (iv) $x_{t}$ and $y_{t}$ are independent of each other (Işı̆̆ıçok, 1994).

The Granger causality test then requires the following processes (Granger, 1981):

1. 1. $y_{t}$ is regressed with delayed y values as in the following model:

$y_{t}=a_{1}+\sum_{j=1}^{m} \gamma_{j} y_{t-j}+e_{1 t}$ and from this regression, the restricted residual sum of squares (RSS) is obtained and called $\operatorname{RSS}_{\mathrm{R}}$. 
2. $y_{t}$ is regressed with both delayed $\mathrm{y}$ values and delayed $\mathrm{x}$ values as in the following model: $y_{t}=a_{1}+\sum_{i=1}^{n} \beta_{i} x_{t-i}+\sum_{j=1}^{m} \gamma_{j} y_{t-j}+e_{1 t}$ and the sum of the unrestricted residual sum of squares (RSS) is obtained from this regression and called $\mathrm{RSS}_{\mathrm{U}}$.

3. The zero and alternative hypothesis are generated as follows:

$H_{0}: \sum_{i=1}^{n} \beta_{i}=0$ or $x_{t}$ causes $y_{t}$.
$H_{1}: \sum_{i=1}^{n} \beta_{i} \neq 0$ or $x_{t}$ causes $y_{t}$.

4. The $\mathrm{F}$ statistic is calculated on the coefficient constraints $(k=m+n+1)$ that have the $F_{m, n-k}$ distribution.

$$
F=\frac{\left(R S S_{R}-R S S_{U}\right) / m}{R S S_{U} /(n-k)}
$$

If the calculated $\mathrm{F}$ value exceeds the F-critical value, the null hypothesis is rejected. Thus, the theoretical expression explains the situation in which the accumulation of financial capital leads to the accumulation of human capital or vice versa.

For the Granger causality test, it is necessary to determine the number of lags in the models. Since the Granger causality test is based on the VAR model, the number of lags should be determined by using similar criteria to the Akaike and Schwartz' Information Criterion according to the VAR model.

Within the framework of the present study, firstly, the variables were investigated by using the Augmented Dickey-Fuller (ADF) Test to decide whether they included unit roots or not for the following models: (i) Non-stationarity non-trend stationarity, (ii) Stationarity non-trend stationarity (iii), and Stationarity and trend stationarity.

Table 2. Unit root test results

\begin{tabular}{lllll}
\hline Variable & Degree & Model & t- Statistics & p-value \\
\hline FINANCE & Level & Non-stationarity non-trend stationarity & 1.55 & 0.96 \\
\hline FINANCE & Level & Stationarity non-trend stationarity & -0.86 & 0.77 \\
\hline FINANCE & Level & Stationarity and trend stationarity & $\mathbf{- 6 . 7 7}$ & $\mathbf{0 . 0 0}$ \\
\hline HUMAN & Level & Non-stationarity non-trend stationarity & 0.56 & 0.83 \\
\hline HUMAN & Level & Stationarity non-trend stationarity & -1.26 & 0.63 \\
\hline HUMAN & Level & Stationarity and trend stationarity & -1.92 & 0.60 \\
\hline HUMAN & First Difference & Non-stationarity non-trend stationarity & $\mathbf{- 4 . 3 5}$ & $\mathbf{0 . 0 0}$ \\
\hline HUMAN & First Difference & Stationarity non-trend stationarity & $\mathbf{- 4 . 4 0}$ & $\mathbf{0 . 0 0}$ \\
\hline HUMAN & First Difference & Stationarity and trend stationarity & $\mathbf{- 4 . 2 7}$ & $\mathbf{0 . 0 2}$ \\
\hline
\end{tabular}

According to the results of the unit root test given in Table 2, the FINANCE variable has a statistical value of -6.77 for the stationarity and trend stationarity model and a probability value that is close to 0 . According to this, H0: this model has a unit root. The null hypothesis was rejected for this variable and the result was found that the unit root was not at a $99 \%$ confidence level. 
On the other hand, the unit root test performed for the HUMAN variable did not reject the null hypothesis in the three models. However, when the first order difference of the variable was taken, the null hypothesis of unit root existence was rejected in all three models. Therefore, the HUMAN variable was found to be integrated first degree. Later in the study, the first order difference (HUMAN) of this variable was taken and the related research was conducted.

In order to ensure the stationary (reliability of the analysis) of the series, first the time series must be made stationary. For this purpose, unit root test was performed. The rejection of the null hypothesis, which shows the existence of the unit root, shows that the series is stationary. If a series is not stationary, it is ensured that each variable is made stationary by taking the first order difference. Thus, it can be mentioned that there is a long-term and realistic relationship between the FINANCE and HUMAN variables. In contrast, regressions with non-stationary time series, i.e., time series without unit roots, eliminate a significant relationship between variables but instead cause a fake relationship or fake regression (Banerjee et al, 1993; Enders, 2003).

After the unit root tests were conducted, the VAR model was established for the required length of lag for the Granger causality test and the appropriate number of lags was investigated. The results for the appropriate number of lags are shown in Table 3.

Table 3. VAR model number of lags

\begin{tabular}{lllllll}
\hline Lag & LogL & LR & FPE & AIC & SC & HQ \\
\hline 0 & 92.69 & NA & 0.00 & -13.95 & -13.86 & -13.97 \\
\hline 1 & 105.35 & $19.46^{*}$ & 0.00 & -15.28 & -15.02 & -15.34 \\
\hline 2 & 106.10 & 0.93 & 0.00 & -14.78 & -14.35 & -14.87 \\
\hline 3 & 114.58 & 7.83 & 0.00 & -15.47 & -14.87 & -15.60 \\
\hline 4 & 123.75 & 5.64 & $0.00^{*}$ & -16.27 & -15.49 & -16.43 \\
\hline 5 & $131.09^{*}$ & 2.26 & 0.00 & $-16.78^{*}$ & $-15.83^{*}$ & $-16.98^{*}$ \\
\hline
\end{tabular}

Table 3 shows logarithmic likelihood (LogL), logarithmic likelihood ratio (LR), final prediction error (FPE), Akaike Information Criterion (AIC), Schwartz Information Criterion (SC) and Hannan Quinn Information Criterion (HQ) values. In this context, the $\operatorname{LogL}, \mathrm{AIC}, \mathrm{SC}$, and $\mathrm{HQ}$ values indicated the most appropriate lag number as 5 . On the other hand, LR indicated that the appropriate lag number could be 1 while FPE indicated that this number could be 4 . When all criterion results were considered together, the appropriate lag number was determined as 5 .

The number 5 here denotes the number of $\mathrm{n}$ and $\mathrm{m}$ in the following model:

$$
y_{t}=a_{1}+\sum_{i=1}^{n} \beta_{i} x_{t-i}+\sum_{j=1}^{m} \gamma_{j} y_{t-j}+e_{1 t}
$$

In other words, it shows how many lag numbers of FINANCE and HUMAN will be included in the model. The fact that the lag values of the variables are included makes it possible to make strong predictions for the future (Mucuk \& Alptekin, 2008).

After determining the appropriate number of lag, the relationship between the FINANCE and HUMAN variables was investigated by applying the above-mentioned Granger causality test. The test results are given in Table 4 .

Table 4. Granger causality test results

\begin{tabular}{lll}
\hline Null hypothesis & F-Statistics & Prob. \\
\hline FINANCE is not HUMAN's Granger Cause & 13.53 & 0.07 \\
\hline HUMAN is not FINANCE's Granger Cause & 0.17 & 0.95 \\
\hline
\end{tabular}


According to the results of the Granger causality test (Table 4), the null hypothesis of "financial development is not the Granger cause of human capital" was rejected with a 0.07 probability value and a 13.53 test statistical value. Therefore, it can be said that financial development, at a confidence level of $90 \%$, is the Granger cause of human capital.

On the other hand, the null hypothesis of "human capital is not the Granger cause of financial development" was rejected with a 0.95 probability value and a 0.17 test statistical value. Accordingly, it can be said that human capital is not the Granger cause of financial development.

These results summarize the financial developments in Turkey. The Foreign Investment Promotion Act, which was put into force in 1954 in order to benefit from external sources, is considered a milestone. However, in the pre-1980 period in Turkey, a closed import substitution industrialization model was prevalent (Marinova \& Marinov, 2018). Until the 1970s, financial markets were national markets and regulated by the Bretton Woods system. In 1973, the world economy adopted the free exchange rate regime instead of the fixed exchange rate regime resulting in the removal of capital controls on a large scale. Capital became the most active element in production factors (Mangum \& Philips, 2015). During this period, capital inflows through political entities such as IMF, WB, OECD (Organization for Economic Co-operation and Development) and EIB (European Investment Bank) as well as NATO were providing revisions to the financial markets, however they were not sufficient (Mazier et al, 1999). In the post-1980 period, in order to get rid of bottlenecks, the January 24-Stability Policies were put into practice in Turkey. While foreign trade was liberalizing, the market-focused and export-based economy model was adopted. Funding was provided under the IMF stand-by and WB adjustment loans. With the foundation of the Capital Markets Board in 1982, banks and other financial institutions were subject to the Board's supervision. In the same year, commercial banks were allowed to hold foreign exchange positions. In 1983, the Saving Deposit Insurance Fund (TMSF) was created. The exchange rate regime was largely liberalized by the Decree No. 30. In 1986, the Istanbul Stock Exchange began to operate as a government domestic debt security market. In 1988, foreign exchange markets were established within the CBRT. The economic and financial reforms carried out in the 1980s were completed in 1989 by Decree No. 32. Thus, the entry and exit of capital market instruments, residents in Turkey to use loans from foreign banks and to invest in foreign countries became free (Karabiylk, 2004; Nar, 2014b; OECD, 1999).

Analyzing financial developments in Turkey in the context of globalization and liberalization activities is important. The reason for this is that financial systems (foreign exchange market-stock exchange-money and capital markets) are the main determinants of a country's development level and stability (Goldsmith, 1969; World Bank, 2013). According to these determinants, financial development in Turkey increases the effectiveness of human capital in addition to making a greater contribution to economic growth (OECD, 1999).

\section{Conclusion}

This study investigated the relationship between the finance and human capital variables and determined that, in Turkey, the finance variable has positive effects on human capital while there is no causal relationship from human capital to financial development.

The analysis results of the present study were in compliance with similar studies in the literature. For example, in a study conducted by Chenery (1986) on data from 1963 to 1975 of Turkey, the capital factor weighted more heavily in the economy than the labor factor. The most important contribution to growth rates was the capital factor at 55\%. In a study conducted in 2006 by the Turkish Industry and Business Association (TUSIAD) for the period of 1972-2000, the capital factor had the most significant contribution to national income with a percentage over $60 \%$, while the human factor remained around the levels of 25-30\%. According to the State Planning Organization (DPT) data from the period of 2008-2010, capital was the production factor that makes its weight felt compared to labor in the economy with a $45 \%$ share. As financial development accelerates, the accumulation of human capital also increases. From the 1980s onwards, decreasing travel expenses and innovations in the field of computer and telecommunication have increased the size of the global capital. As a reflection of this process, significant direct and indirect capital inflow into Turkey was realized. Strict control over capital was abolished, and restrictions on acquisitions and mergers eased. Obstacles in terms of accessing capital markets and fiscal pressure (tax pressure) decreased. With the adoption of the International Arbitration Law, attractive measures were implemented to encourage foreign direct investments. In the post-2000 period, efforts to organize and regulate the banks, one of the leading financial intermediary institutions, accelerated financial development. Moreover, the reduction of operational and public obligations of institutions such as private pension funds, insurance companies, and savings funds, as well as banks, reduced the risk perception in financial markets and increased the credibility in the economy. Progress in the financial field directly increased investment in human. 
However, according to another result of the present study, human capital cannot be the cause of financial development. Understanding the underlying rationale of the problem requires looking at the "education" and "health" services, i.e., the main components of the human variable. In Turkey, quality problems are very clear in education, especially in university education. As of 2017, there are a total of 179 universities in Turkey, with 112 of them state universities and 67 of them private. Vocational schools of the private sector are not included in this number. Taking these figures into account, it is possible to say that there are more than 200 higher education institutions in Turkey. The number of universities has been booming since 2003 when it was only 53 and since then, universities have become available to a much wider section of society. This situation can be seen more clearly when Günay \& Günay (2016) investigated the higher education gross schooling ratio of countries between the years of 2000 and 2013. According to their research, Turkey ranked 9th among the upper-middle-income countries with a 94\% gross enrollment rate, which passes many high-income countries. However, according to data from Universitas, one of the leading global networks in evaluating higher education institutions, Turkey ranks 37 among 50 countries with regards to higher education quality. Despite leaving behind many countries in terms of higher education enrollment rates, Turkey is recognized in the category of problematic countries in terms of the ability to create added value and produce income. A similar situation can be seen regarding health expenditures. Although the total health expenditure has increased 2.5 times in the last decade, Turkey is still behind the average for the OECD countries, which is 3,339 USD. When the level of health spending per capita in the OECD countries is examined, Turkey ranks last with 767 USD. In contrast, the health spending per capita in Mexico is 977 USD, in Estonia is 1,303 USD and in Greece is over 2,500 USD. This brief summary of the situation in Turkey shows that there is no increase in health spending in real terms. In other words, health expenditures are increasing in parallel with the increasing population of the country. As a result, health expenditures that are not increasing in a rational sense make the health area problematic in terms of the human index (Bilici \& Bilici, 2011; Sözcü, 2014; Universitas, 2017).

Therefore, if the causality relation from human capital to financial development is to be built on solid foundations in the short and long term, the quality problem should be overcome in education. For this purpose, the establishment of unnecessary universities in higher education should be prevented and excessive staffing should be avoided. Universities should not be turned into institutions that easily distribute diplomas. The unnecessary departments must be shut down. In order to prevent the closure of provincial universities, the search for a solution to the problem by increasing the quota of foreign students should be abandoned. In addition, serious measures should be taken to create a healthier society. Considering that a significant part of the health services is provided by the state, it is necessary to revise the social security system that is near to the point of being dysfunctional. Immediate creation of effective public policies aimed at protecting public health, particularly food safety, is also very important for the sustainability of future generations.

\section{References}

Agenor, P. R., \& Montiel, P. J. (2015). Development Macroeconomics. New Jersey: Princeton University Press. https://doi.org/10.1515/9781400866267

Banerjee, A., Dolado, J., Galbraith, J. W., \& Hendry, D. (1993). Co-Integration, Error Correction, and the Econometric Analysis of Non-stationary Data. Oxford University. https://doi.org/10.1093/0198288107.001.0001

Barro, R. J. (1990). Goverment Spending in A Simple Model of Endogenous Growth. The Journal of Political Economy, 98(5), 103-125. https://doi.org/10.1086/261726

Bartolo, A. D. (1999). Human Capital Estimation Through Structural Equation Models With Some Categorical Variables. International Workshop on Correlated Data: Estimating Function Approach. Trieste-Italy. Retrieved from http://iriss.ceps.lu/documents/irisswp4.pdf

Bencivenga, V. R., \& Smith, B. D. (1991). Financial Intermediation and Endogenous Growth. The Review of Economic Studies, 58(2), 195-209. https://doi.org/10.2307/2297964

Bilici, N., \& Bilici, A. (2011). Кати Maliyesi. Seçkin yayıncılık, Ankara. Retrieved from https://www.seckin.com.tr/kitap/n/352643166/title/kamu-maliyesi-nurettin-bilici.html

Bishop, M. (2004). Essential Economics. London: Published by Profile Books Ltd.

Bottazzi, L., Rin, M. D., \& Hellmann, T. (2004). Active Financial Intermediation: Evidence on the Role of Organizational Specialization and Human Capital. ECGI Working Paper. http://dx.doi.org/10.2139/ssrn.569602

Brian, N. (2009). A comprehensive Dictionary of Economics. Publisheed by: Abhishek Publications. 
Chenery, H. (1986). Growth and Transformation. In H. Chenery, S. Robinson, \& M. Syrquin (Eds.), Industrialization and Growth. World Bank Research Publications. Retrieved from http://documents.worldbank.org/curated/en/714961468135943204/pdf/NonAsciiFileName0.pdf

Demir, E., Saatçioğlu, Ö., \& İmrol, F. (2016). Uluslararası Dergilerde Yayımlanan Eğitim Araştırmalarının Normallik Varsayımları Açısından İncelenmesi. Curr Res Educ, 2(3), 130-148. Retrieved from http://dergipark.gov.tr/download/article-file/286815

Demirci, S., \& Özyakışır, D. (2017). Finansal Gelişmişlik ve Beşeri Sermaye Arasındaki İlişki: Türkiye için Zaman Serileri Analizi. Ekonomik Yorumlar, 624(2), 25-39. Retrieved from http://www.ekonomikyorumlar.com.tr/files/articles/152820006555_2.pdf

DPT. (2007). 2007 Yllı Katılım Öncesi Ekonomik Programı. Ankara. Retrieved from https://www.ab.gov.tr/...katilim_oncesi_ekonomik_program/

Dwivedi, D. N. (2010). Principles of Economics. Vikas Publication House Pvt Ltd.

Enders, W. (2003). Applied Econometric Time Series. Wiley, John \& Sons.

Evans, A. D., Green, C. J., \& Murinde, V. (2002). Human Capital and Financial Development in Economic Growth: New Evidence Using the Translog Production Function. International Journal of Finance \& Economics, 7(2), 123-140. https://doi.org/ 10.1002/ijfe.182

Feldman, D. H., \& Gang, I. N. (1990). Financial Development and the Price of Services. Economic Development Cultural Change, 38(2), 341-352. https://doi.org/10.1086/451796

Ferreira, S., \& Hamilton, K. (2010). Comprehensive Wealth, Intangible Capital, and Development. Policy Research Working Paper 5452. The World Bank. https://doi.org/10.1596/1813-9450-5452

Gazetesi, S. (2014). Işse Türkiye'nin hali. Retrieved November 10, 2018, from https://www.sozcu.com.tr/2014/saglik/iste-saglikta-cag-atladi-denen-turkiyenin-hali-441006/

Goldin, C. (2014). Human Capital. Harvard University and National Bureau of Economic Research. https://doi.org/10.1007/978-3-642-40458-0_23-1

Goldsmith, R. W. (1969). Financial Stracture and Development. London New Haven and Yale Universtiy Press. Retrieved from http://www.sciepub.com/reference/137782

Granger, C. W. J. (1981). Some Properties of Time Series Data and Their Use in Econometric Model Specification. Journal of Econometrics, 16(1), 121-130. https://doi.org/10.1016/0304-4076(81)90079-8

Greenwood, J., \& Jovanovich, B. (1990). Financial Development, Growth, and the Distribution of Income. The Journal of Political Economy, 98(5), 1076-1107. https://doi.org/10.1086/261720

Günay, D., \& Günay, A. (2016). Dünyada ve Türkiye'de Yükseköğretim Okullaşma Oranları ve Gelişmeler. Yükseköğretim ve Bilim Dergisi, 6(1), 13-30. https://doi.org/10.5961/jhes.2016.139

Haan, J. D., Oosterloo, S., \& Schoenmaker, D. (2009). European Financial Markets and Institutions. Cambridge University Press.

Hamilton, K., \& Liu, G. (2013). Human Capital, Tangible Wealth, and the Intangible Capital Residual. Statistics Working Papers, OECD Publishing. https://doi.org/10.1596/1813-9450-6391

Hatemi, J. A., \& Shamsuddin, M. (2016). The Causal Interaction Between Financial Development and Human Development in Bangladesh. Applied Economics Letters, 23(14), 995-998. https://doi.org/10.1080/13504851.2015.1128066

Işı̆̆ıı̧ok, E. (1994). Zaman Serilerinde Nedensellik Çözümlemesi. Bursa: Uludağ Üniversitesi Basım Evi. Retrieved from https://www.seckin.com.tr/kitap/569883795

Kalaycı, Ş. (2006). SPSS Uygulamalı Çok Değişkenli İstatistik Teknikleri. Ankara: Asil Yayıncılık.

Karabıyık, L. E. (2004). Küreselleşme Sürecinde Finansal Krizler ve Etkileri. Marmara Kitabevi. Retrieved from https://www.seckin.com.tr/kitap/242332191

Kendall, J. (2009). Local Financial Development and Growth. Policy Research Working Paper, WB. https://doi.org/10.1596/1813-9450-4838

Kendall, J. (2012). Local Financial Development and Growth. Journal of Banking \& Finance, 36(5), 1548-1562. https://doi.org/10.1016/j.jbankfin.2012.01.001 
King, R. G., \& Levine, R. (1993). Finance, Entrepreneurship and Growth: Theory and Evidence. Journal of Monetary Economics, 32(3), 513-542. https://doi.org/10.1016/0304-3932(93)90028-E

Kyrtsis, A. A. (2010). Financial Markets and Organizational Technologies. First published, Palgrave Macmillan. https://doi.org/10.1057/9780230283176

Loayza, N., \& Ranciere, R. (2005). Financial Development, Financial Fragility and Growth. IMF Working Paper. https://doi.org/10.1596/1813-9450-3431

Lorimer, W. (2012). The History of Financial Transactions From Barter to M-Commerce. Retrieved April 16, 2018, from www.munKNEE.com

Lucas, R. E. (1988). On the Mechanics of Economic Development. Journal of Monetary Economics, 22(1), 3-42. https://doi.org/10.1016/0304-3932(88)90168-7

Mangum, G. L., \& Philips, P. (2015). Three Worlds of Labour Economics. Routledge.

Marinova, S. T., \& Marinov, M. A. (2018). Motives and Strategies for Foreign Direct Investment in Central and Eastern Europe. In S. Marinova, \& M. Marinov (Eds.), Foreign Direct Investment in Central and Eastern Europe. Publisher: Routledge. https://doi.org/10.4324/9781315198965

Mattelart, A. (1996). La Mondialisation de la Communication. Presses Universitaires de France. Retrieved from https://www.puf.com/content/La_mondialisation_de_la_communication

Mazier, J., Baslé, M., \& Vidal, J. F. (1999). When Economic Crises Endure. Publisher: M.A Sharpe Inc. Retrieved from https://www.amazon.com/gp/product/0585179824/ref=x_gr_w_bb?ie=UTF8\&tag=x_gr_w_bb

Mosco, V. (2009). The Political Economy of Communication (2nd ed.). SAGE. https://doi.org/10.4135/9781446279946

Mucuk, M., \& Alptekin, V. (2008). Türkiye'de Vergi ve Ekonomik Büyüme İlişkisi: VAR Analizi (1975-2006). Maliye Dergisi, $155(2), \quad 159-174 . \quad$ Retrieved from maliye_dergisi/yayinlar/md/155/10.Mehmet.MUCUK_Volkan.ALPTEKIN.pdf

Nar, M. (2014a). Credit Risk Management in the Financial Markets. Journal of Applied Finance and Banking, 4(4), 107-125. Retrieved from http://www.scienpress.com/Upload/JAFB/Vol\%204_4_8.pdf

Nar, M. (2014b). Capital Controls, New IMF Policies and the Practice of Turkey. American Journal of Economics, 4(6), 226-239. https://doi.org/10.5923/j.economics.20140406.02

Nar, M., \& Nar, M. Ş. (2019). An Updated Assessment of the OECD's Quality of Life Index. Problemy Ekorozwoju - Problems of Sustainable Development, 14(1), 7-18.

OECD. (1999). Economic Surveys. OECD Publications Services, Paris. Retrieved from https://www.oecd-ilibrary.org/economics/oecd-economic-surveys-turkey-1999

Outreville, J. F. (1999). Financial Development, Human Capital and Political Stability. Working Paper, No. 142, UNCTAD. Retrieved from https://core.ac.uk/download/pdf/7043257.pdf

Parente, S. L., \& Prescott, E. C. (1994). Barriers to Technology Adoption and Development. Journal of Political Economy, 102(2), 298-321. https://doi.org/10.1086/261933

Rebelo, S. (1991). Long-Run Policy Analysis and Long-Run Growth. Journal of Political Economy, 99(3), 500-521. https://doi.org/10.1086/261764

Romer, P. M. (1986).Increasing Returns and Long-Run Growth. Journal of Political Economy, 94(5), 1002-1037. https://doi.org/10.1086/261420

Roubini, N., \& Sala-i-Martin, X. (1995). A Growth Model of Inflation, Tax Evasion and Financial Repression. Journal of Monetary Economics, 35(2), 275-301. https://doi.org/10.1016/0304-3932(95)01192-Q

Rutherford, D. (2002). Routledge Dictionary of Economics (2nd ed.). Taylor \& Francis. https://doi.org/10.4324/9780203000540.ch1

Sharma, K. (2016). Financial Development, Human Capital, and Economic Growth: A Cross Country Analysis. Masters Theses, by Eastern Illinois University. Retrieved from http://thekeep.eiu.edu/theses/2430

Tiexeria, P. (2007). Jacob Mincer and the Centrality of Human Capital for Contemporary Labor Economics. Retrieved September 16, 2017, from http: http://hisreco.org/assets/pdf/2007/5_Teixeira.pdf 
TUSIAD. (2006). Eğitim ve Sürdürülebilir Büyüme. Istanbul: Türk Sanayicileri ve Iş Insanları DerneğiYayınları.

Universitas. (2017). Ranking Map. University of Birmingham. Retrieved from www.universitas21.com

Wal, S. (1999). International Encyclopaedia of Child Development: Priorities for 21 st Century. Sarup \& Sons.

Wikipedia. (2017). Financial Transaction. Retrieved September 22, 2017, from https://en.wikipedia.org/wiki/Financial_transaction

Williams, R. (2011). An Introduction to Trading in the Financial Markets. Elsevier Inc. https://doi.org/10.1016/B978-0-12-374839-3.00002-6

World Bank.(2013). Global Fnancial Development Report 2013: Rethinking the Role of the State in Finance. https://doi.org/10.1596/978-0-8213-9503-5

Yalta, T. (2011). Zaman Serileri Ekonometrisine Giriş. Retrieved August 12, 2018, from http:file:///C:/Users/admin/Downloads/ekonometri2-tuba-24-duraganlik 